\title{
The Effectiveness of Learning Circle Assisted by Geogebra Software Reviewed from Creative Thinking and Visual Thinking Ability of Junior High School Students
}

\author{
Nuryadi $^{1, *}$, Ahmad Fithriadhy ${ }^{2}$, Dafid Slamet Setiana ${ }^{3}$, Zona Asha Tigara ${ }^{1}$, \\ Melania Eva Wulanningtyas ${ }^{1}$ \\ ${ }^{1}$ Mathematic Education Study Program, University of Mercu Buana Yogyakarta, Indonesia \\ ${ }^{2}$ Department of Maritime Technology, Universiti Malaysia Terengganu, Malaysia \\ ${ }^{3}$ Mathematic Education Study Program, Sarjanawiyata Tamansiswa University of Yogyakarta, Indonesia
}

Received August 17, 2020; Revised December 9, 2020; Accepted December 20, 2020

\section{Cite This Paper in the following Citation Styles}

(a): [1] Nuryadi, Ahmad Fithriadhy, Dafid Slamet Setiana, Zona Asha Tigara, Melania Eva Wulanningtyas , "The Effectiveness of Learning Circle Assisted by Geogebra Software Reviewed from Creative Thinking and Visual Thinking Ability of Junior High School Students," Universal Journal of Educational Research, Vol. 8, No. 12B, pp. 8488 - 8494, 2020. DOI: 10.13189/ujer.2020.082658.

(b): Nuryadi, Ahmad Fithriadhy, Dafid Slamet Setiana, Zona Asha Tigara, Melania Eva Wulanningtyas (2020). The Effectiveness of Learning Circle Assisted by Geogebra Software Reviewed from Creative Thinking and Visual Thinking Ability of Junior High School Students. Universal Journal of Educational Research, 8(12B), 8488 - 8494. DOI: 10.13189/ujer.2020.082658.

Copyright@2020 by authors, all rights reserved. Authors agree that this article remains permanently open access under the terms of the Creative Commons Attribution License 4.0 International License

\begin{abstract}
The development of creative thinking ability was one of the focuses in learning mathematics. Creative thinking is one of the skills needed in a society, so it is necessary to develop these skills as early as possible. This research aims to describe the effectiveness of learning circle assisted by Geogebra software reviewed from creative thinking and visual thinking ability of Junior High School students. This research was a quasi-experimental research using pretest-posttest control group design. The population was all grade VIII student of One State Sedayu Junior High School. Sample of this research was selected by purposive sampling technique. Two classes from eight classes were selected. The experimental class was VIII $\mathrm{F}$ and the control class was VIII G. The experimental class was taught by using Geogebra software while the control class is by using the conventional one. The instruments used on this research were creative thinking test and visual thinking ability test. The result of this research showed that learning circle assisted by Geogebra software is more effective than conventional method for improving creative thinking and visual thinking ability.
\end{abstract}

Keywords Creative Thinking, Visual Thinking, Geogebra

\section{Introduction}

The rapid development of information and communication technology today were rooted from the development of mathematics on number theory, algebra, analysis, probability theory, and discrete mathematics. To keep abreast with technological changes, the students need to master logical, analytical, systematical, critical, creative thinking and collaborative skill from early year $[1 ; 2]$. Those competences are prescribed in the Indonesian National curriculum [3]. It says that the students should have the ability to obtain, manage, and utilize information for the survival in every uncertain condition.

According to National Minister Education Regulation Number 22 Year 2006 explaining the content standards, studying mathematics aims to enable students: (1) 
Understanding mathematical concepts, explaining the interrelationships concepts and applying the concepts or the algorithms, flexibly, accurately, efficiently, and precisely, in problem solving; (2) Using reasoning on patterns and character, carrying out mathematical manipulations in making generalizations, compiling proof, or explaining mathematical ideas and statements; (3) Solving problems include understanding problems ability, designing mathematical models, solving models and interpreting the solutions; (4) Communicating ideas with symbols, tables, diagrams or other media to explain the situation or problem; (5) Having an appreciating usefulness of mathematics ability in life, namely curiosity, attention, and interest in learning mathematics, as well as being tenacious and confident in problem solving [4].

The development of creative thinking ability was one of the focuses in learning mathematics. Creative thinking is the ability of applying complex thinking structures to produce new and original ideas. Creative thinking ability is needed on solving mathematical problems including the formulation steps, interpretation, and problem solved planning [5]. This is in line with Tall that "Mathematical creativity in problem solving is the ability to formulate mathematical objectives and find their innate relationships; it is the capacity to solve problems according to the appropriateness of integrating both the nature of logic-deduction in mathematics education and its evolved concepts into its core." [6].This means that creative thinking in solving mathematical problems is not only the ability to formulate mathematical objects and find interrelated relationships, but also to make conclusions and apply mathematical concepts.

Difficult topics that hindered creative thinking of the students at standard VIII are geometry and measurement since they deal with abstract material and need to be visualized. One of the media facilitating the geometry and measurement learning, particularly circles, is Geogebra software. Several researches have been conducted on its efficacy as learning media. The implementation of reciprocal teaching and learning models assisted by Geogebra could improve students' mathematical communication skills. In this research, teaching materials were delivered through the Guided Discovery learning model assisted by Geogebra software [7]. Yuliani and Suragih [8] argue that guided discovery learning model (guided discovery) is a learning model that places the teacher as a facilitator, while students are encouraged to think for themselves so that they can find general principles based on the material or data provided by the teacher. To solve mathematical problems, the students need thinking ability and visual thinking abilities.

The obstacles of learning geometry in class were caused by two reasons; the first one is teacher who faces high visualization material power [9-11] and the second one is effectiveness of time [5]. If the teacher conveys the geometry space concept through a Cartesian diagram then draws it manually without using tools, this will obviously require a lot of time while the times are limited. When viewed from time effectiveness, conventional learning method needs more time to achieve optimal results. Visual thinking is a process of formulating, linking ideas, and discovering new patterns [5;12]. Visual thinking is an iteration process that used mock models and sketches for developing the ideas in quantitative and qualitative manners [13-14]. That visualizations and symbolically are important to learn more abstract high-level mathematics [15]. Visualization becomes important when student do not get concrete objects to be manipulated. The proposed Virtual Manipulates and Whiteboard systems can help students to understand the process of solving geometry problems, such as using various solving strategies, as well as exposing geometric misunderstandings [16]. Visualization is also used to assist in proving the integrity of the functions. So, it can be concluded that visual thinking is an intuitive intellectual process as well as visual imagination ideas, both mental and drawing images.

The creative thinking ability of class VIII SMP Negeri 1 Sedayu was relatively low. It was proven by the observations and explanations given by teachers that among 31 students in the class, only 3-5 students were able to answer or to solve mathematics questions. From the interview, it is found that students still had difficulty in representing problems on visual images, graphics, and diagram forms or written explanations. Out of 31 students observed, only 10-13 students were able to do it. Thus, it can be inferred that creative thinking and visual thinking abilities of students belong to low categories.

Creative thinking is a mind rule trained by observing intuition, animating imagination, expressing new possibilities, opening amazing perspectives, and developing unexpected ideas [17]. That creative thinking is one of the skills needed in a society, so it is necessary to develop these skills as early as possible [18]. Nuha et al [19] argue that these creative thinking skills are useful for the future therefore they must have these skills. Based on [20], creativity can be assessed based on five habits of creative thinking namely Inquisitive, Imaginative, Persistent, Collaborative, and Disciplined.

There are four aspects of creative thinking---smooth thinking, flexible thinking, original thinking, and detail thinking [21]. One way to understand the concept is to use visualization. Some studies show the importance of visualization and visual reasoning for learning mathematics [22]. Visual thinking is organizing process and managing information by viewing through pictures, graphs, colors, and diagrams [23]. Visual thinking is something active thinking and analytical processes for understanding, interpreting and producing visual messages interaction between seeing, imagining, describing, and verbal thinking [24]. The steps of visual thinking according to Bolton are (1) Looking, identifying problems 
and their interrelationships which are viewing and gathering activities; (2) Seeing, understanding problems and opportunities by selecting and grouping activities; (3) Imagining, generalizing steps to find solutions, pattern recognition activities; (4) Showing and Telling, explaining what has seen and obtaining then communicates it [25].

Geogebra is a dynamic mathematics software supervised by the General Public License (GPL) developed by Howenwarter in 2002 through his master's thesis project of Salzburg University [26]. Geogebra as dynamic mathematics software gives experience to construct and explore geometric models and structures dynamically, so learning mathematics becomes more explorative because students can understand relationship between analytic and visual representations concepts also interrelationships among other mathematics concepts directly. This is in line with Preiner who said that Geogebra software can be used to visualize mathematical concepts and create mathematics learning materials [27]. Thus, Geogebra is an open source application program used as a tool in learning mathematics specifically algebra and geometry.

The using of Geogebra program in mathematics learning provides several advantages 1) Drawing geometry more quickly and thoroughly faster than using a pencil, ruler, or compass. 2) Animation facilities existence and manipulation motions (dragging) provide a clearer visual experience to help students understanding geometry concept. 3) It can be used as feedback/ evaluation to ensure that has been drawing correctly. 4) Make easier investigating or showing the characteristic applied on geometry object for both teacher and student [28].

Conventional learning is a teaching method involving instructors and the students interacting in a face-to-face manner in the classroom [29]. These instructors initiate discussions in the classroom and focus exclusively on knowing content in textbooks and notes. Conventional learning student placed as an object who receives all information passively [30]. In conventional learning, the lesson materials are delivered through lecturing, question and answers, and assignments methods. Conventional learning is done by one way while in Geogebra software, the students can do two activities simultaneously both listening and recording.

So, this research aims to describe the effectiveness of learning circle assisted by Geogebra software reviewed from creative thinking and visual thinking ability of Junior High School students

\section{Research Methods}

This research was conducted within quasi-experimental research. The main characteristic of quasi experimental design is development of true experimental design which has a control group but cannot fully control external variables experiment affected. While, pre-post control group design was used. In this experiment, there were two groups randomly chosen, experimental group and control group. The purpose of pretest was to find out creative thinking and visual thinking ability of the students before giving treatment. The experimental learned mathematics on circle object by using Geogebra while the control class had mathematics on circle object using conventional methods.

The treatments were given every day from January of $23^{\text {rd }}$ until February of $28^{\text {th }}$, 2020. After giving the treatment, post-test was conducted to measure their creative thinking ability and visual thinking ability. The populations of this research were all VIII grade students of SMP N 1 Sedayu consisting of eight classes with total number 222 students. From eight classes, only two classes were chosen at random. They were VIII $\mathrm{F}$ as the experimental class and VIII G as the control class. The independent variable in this research was learning mathematics on circle object using Geogebra and the dependent variable was the creative thinking ability of students and visual thinking ability of students.

This research used description question test instrument. This test instrument was used to measure creative thinking ability and visual thinking abilities of the students. Expert judgment was asked to guarantee the content validity of the instrument. In this research, the expert was Iman Nurwoko a mathematics teacher at SMP N 1 Sedayu. The result of validity test using expert judgment is shown in research finding.

At the data analysis stage, the collected data must be processed through the analysis prerequisite test which includes the normality test and the homogeneity test. The normality test conducted is the multivariate normality test. Meanwhile, the homogeneity test was carried out in a multivariate manner using the Box's $M$ test. The result of the normality test and the homogeneity test is shown in research finsing before effectiveness test.

Followed by the average similarity test which is used to determine whether or not there is a difference in the average initial ability of students in the control class and the experimental class, the data used were the pretest results of students' creative thinking abilities and visual thinking in both classes.

After the two samples were given different treatment, the data obtained from the results of the preliminary ability test and the final ability test were analyzed to obtain a score of increase (gain) in both classes [31]. This analysis aims to determine the magnitude of the increase in students' creative thinking and visual thinking skills in the experimental class and the control class. And finally, to measure the effectiveness of Geogebra-assisted circle learning in terms of creative thinking skills and visual thinking skills, a one sample t-test was used. 


\section{Research Finding}

First, the research finding will show in the Table 1 about the result of the validity test using expert judgment.

Table 1. The Result of Validation ofTeaching Materials based on Geogebra

\begin{tabular}{|c|c|c|}
\hline No & Aspect & Value \\
\hline 1 & Layout & 5 \\
\hline 2 & Language & 5 \\
\hline 3 & Content & 5 \\
\hline 4 & Navigation & 5 \\
\hline
\end{tabular}

Table 1 shows that the develop instrument in the teaching materials based on Geogebra can be used without revision.

Then, the data in Table 2 below present the creative thinking abilities test result on experimental class and control class.

Table 2. Creative Thinking Abilities Test Result

\begin{tabular}{|c|c|c|}
\hline \multirow{2}{*}{ Class } & \multicolumn{2}{|c|}{ Average } \\
\cline { 2 - 3 } & Before Treatment & After Treatment \\
\hline Experiment & 36,75 & 84,94 \\
\hline Control & 37,06 & 73,44 \\
\hline
\end{tabular}

Table 2 shows that average score of creative thinking abilities test result before treatment on experimental class was 36.75 and control class was 37.06. After treatment, there was an increasing about 48.19 point so the average became 84.94 for experimental class. While, there was an increasing about 36.38 point so the average became 73.44 for control class. Thus, it can be inferred that the average value of experimental class after being given treatment is better than that of control class.

Table 3 below presents the visual thinking abilities test result at experimental class and the control class:

Table 3. Visual Thinking Abilities Test Result

\begin{tabular}{|c|c|c|}
\hline \multirow{2}{*}{ Class } & \multicolumn{2}{|c|}{ Average } \\
\cline { 2 - 3 } & Before Treatment & After Treatment \\
\hline Experiment & 37,56 & 85,88 \\
\hline Control & 37,81 & 75,97 \\
\hline
\end{tabular}

Table 3 shows that average score of visual thinking abilities test result before treatment on experimental class was 37.56 and control class was 37.81 After treatment, there was an increasing about 48.32 points so the average became 85.88 for experimental class. While, there was an increasing about 38.16 points so the average becomes 75.97 for control class. Based on these data, it can be inferred that the average score of experimental class after being given treatment is better than that of control class.
After that, the normality test and the homogeneity test are conducted before testing the hypothesis. The normaity test before and after treatment in the experiment class and control class shows that scatter-plot tends to form a straight line with p-value 0,000 . So, this datum is declared normal. Next, the homogenity test before treatment in the experiment class and control class has 2,723 box's M value, and then after treatment in the experiment class and control class has 5,959 box's M value. So, this datum is declared homogeneity.

After the data declared normal and homogeneity, the testing is continued with the average similarity test used to find out the student average initial ability differences on control class and experimental class. The data used were students' creative thinking ability pretest result and student visual thinking ability pretest result in both classes. Average similarity test is carried out through the t-test with these following formula:

$$
t=\frac{\bar{x}_{1}-\bar{x}_{2}}{s \sqrt{\frac{1}{n_{1}}+\frac{1}{n_{2}}}} \text { while } S=\frac{\left(n_{1}-1\right) s_{1}{ }^{2}+\left(n_{2}-1\right) s_{2}{ }^{2}}{n_{1}+n_{2}-2}
$$

Notes:

$\bar{x}_{1} \quad$ Experimental class pretest average score

$\bar{x}_{2} \quad$ Control class pretest average score

$n_{1} \quad$ Experiment class student proportion

$n_{2} \quad$ Control class student proportion

$s_{1} \quad$ Experimental class standard deviation

$S_{2} \quad$ Control class standard deviation

$S \quad$ Mix standard deviation

Table 4 shows the average similarity initial abilities student test result:

Table 4. Average Similarity Initial Abilities Student Test Result

\begin{tabular}{|c|c|}
\hline Variable & Significance \\
\hline Creative Thinking Abilities & 0,827 \\
\hline Visual Thinking Abilities & 0,860 \\
\hline
\end{tabular}

Table 4 shows that significance value for creative thinking ability was 0.827 . This means no creative thinking average initial ability differences between experiment class and control class as the visual thinking ability has 0.860 on the significance value. Thus, it can be concluded that between experimental class and control class, there is also no difference in visual thinking average initial ability of students.

Both of two samples were given different treatment, data from initial ability test result and final ability test result were analyzed to obtain an increase score (gain) among the classes. This analysis aims to determine the increasing score of creative thinking abilities student and visual thinking abilities students on experimental class and control class. Gain results interpreted by using an adapted classification are as follows on Table 4: 
Table 5. Gain Index Criteria

\begin{tabular}{|c|c|}
\hline Gain Index (g) & Criteria \\
\hline $0.70-1.00$ & High \\
\hline $0.30-0.69$ & Middle \\
\hline $0.00-0.29$ & Low \\
\hline
\end{tabular}

The increasing gain score of creative thinking ability is shown on Table 6:

Table 6. Increasing Creative Thinking Ability

\begin{tabular}{|c|c|c|}
\hline Class & Gain Index & Criteria \\
\hline Experiment & 0.76 & High \\
\hline Control & 0.59 & Middle \\
\hline
\end{tabular}

Table 6 shows that creative thinking ability on experimental class has the increasing gain score of 0.76 . This means that there was a high creative thinking abilities student increase. Whereas, increasing gain score on control class was much lower with totally 0.59 and it belongs to middle category.

The increase gain score through visual thinking ability is shown in table 6 below:

Table 6. Increasing Visual Thinking Ability

\begin{tabular}{|c|c|c|}
\hline Class & Gain Index & Criteria \\
\hline Experiment & 0.78 & High \\
\hline Control & 0.62 & Middle \\
\hline
\end{tabular}

Table 6 shows that visual thinking ability in experimental class has gain score of 0.78 . This expect high improvement in visual thinking abilities student whereas control class has archived only 0.62 . It seems much lower gaining score that belongs to moderate category. Based on the analysis, it can be concluded that after treatment, there was a high increasing on creative thinking ability and visual thinking ability on experimental class.

Learning mathematics on circle object using Geogebra is effective to creative thinking ability and visual thinking ability if the average score of experimental class students achieves Minimum Mastery Criteria which is equal or more than 75. This effectiveness test is carried out on creative thinking ability student and visual thinking ability students after treatment.

To find out the effectiveness learning mathematics on circle object using Geogebra especially on creative thinking ability and visual thinking ability, one sample t-test should be given.

Circle learning assisted with Geogebra softaware is effective in terms of creative thinking skills and visual thinking abilities if the average value of the experimental class students meets the Minimum Completeness Criteria (KKM) that has been set at school, namely 75 . This effectiveness test is carried out on the value of creative thinking skills and students' visual thinking abilities after being given treatment.
From the results of hypothesis testing with the one sample t-test statistic on the variable of creative thinking ability, the significance value is 0.000 so that H_0 is rejected. This means that learning circles assisted by Geogebra software are effective in terms of creative thinking abilities. As for the visual thinking ability variable, based on the results of hypothesis testing with the one sample t-test statistic, it was obtained a significance value of 0.000 so that $\mathrm{H}_{-} 0$ was rejected. Thus, it can be concluded that circle learning assisted by Geogebra software is effective in terms of visual thinking abilities.

To find out which method is more effective between learning circles assisted by Geogebra software and conventional methods in terms of creative thinking and visual thinking abilities, first a multivariate test is carried out. The multivariate test used is the Hotelling $\mathrm{T} \wedge 2$ test. This test is conducted to determine whether there is a difference in effectiveness between the two methods used. The data analyzed were data obtained from the posttest results of students' creative thinking abilities and visual thinking after treatment. If $\mathrm{H}_{-} 0$ is rejected, then the hypothesis testing can be done by using the univariate test using the independent samplet-test. This examination is used to determine a more effective method between circular learning with Geogebra software and conventional learning on students' creative thinking and visual thinking skills. Based on the results of the $\mathrm{T} \wedge 2$ Hotelling test that has been carried out, there are differences in the average value of creative thinking and visual thinking skills in the experimental class and the control class after treatment. The posttest average score of the ability to think creatively in the experimental class is higher than the control class. The results of further analysis showed that there was a high increase in the ability to think creatively in the experimental class.

Apart from the ability to think creatively, an aspect that also improved in the experimental class after being given treatment was the ability to visual think. Based on the results of the visual thinking posstest, it can be seen that the average score obtained by students in the experimental class is much higher than the control class. There has been a high increase in students' visual thinking abilities between before being given treatment and after being given treatment.

\section{Discussion}

From the hypothesis test result using one sample t-test on creative thinking ability, it is obtained significance value of 0,000 , then $H_{0}$ is rejected. It means learning mathematics on circle object using Geogebra is effective to creative thinking ability. Besides, for visual thinking ability, it is obtained significance value of 0,000 so $H_{0}$ is rejected. Thus, it can be inferred that learning 
mathematics on circle object using Geogebra is effective for visual thinking ability. In order to find out which one is more effective whether learning mathematics on circle object using Geogebraor conventional method for creative thinking ability and visual thinking ability, multivariate test was given. The multivariate method here was $\mathrm{T}^{2}$ Hotelling test.

The data used for this kind of test were post-test scores. The average posttest score of creative thinking ability on experimental class was higher than the control one. The results from further analysis showed that there was a high score increasing on creative thinking ability experimental class. Besides creative thinking ability, the visual thinking ability was also improved. Based on visual thinking post-test, the average post-test score was higher than that of control class. The result from further analysis showed that there was a high score increasing on visual thinking ability after treatment.

Furthermore, from the result of this research, it can be concluded learning mathematics on circle object using Geogebra is more effective in improving creative thinking ability and visual thinking ability than the conventional methods [32-33].They said the use of Geogebra dynamic geometry software has the potential to improve and enhance students' critical knowledge and skills, creative and innovative thinking towards supporting problem-based learning as an approach in 21st century learning [34-35].

\section{Conclusion}

Based on the results of this research, there were several conclusions can be withdrawn: (1) learning mathematics on circle object using Geogebra is effective for improving creative thinking ability of the students, (2) learning mathematics on circle object using Geogebra is effective for improving visual thinking ability students, (3) learning mathematics on circle object using Geogebra is more effective for improving creative thinking ability and visual thinking ability than conventional methods. There are several factors that caused those effectiveness. One of them is that Geogebrais gives new experience to the students for constructing, exploring geometric models, structure, or graph dynamically. As the result, when the students learned mathematics, they become more active. Through Geogebra, the student can see directly the relationship between analytical and visual representations of a concept as well as the interrelationships among mathematical concepts. Thus, Geogebra indirectly encourages students to be more creative. The factors that caused learning using Geogebra is effective for improving visual thinking ability are that it can visualize mathematical concepts and create mathematics learning materials. Dynamic visualization can be used for explaining concepts so they can understand mathematical concepts, ideas, object, and materials easily. It is suggested that Geogebra can be an alternative media to convey mathematics concept in the class room. For other researchers who want to do similar research, they should add another variation of questions and prepare more simulations well to support learning research and view the Geogebra from other aspects, such as motivation learning, spatial ability, and problem-solving abilities

\section{REFERENCES}

[1] A. R. As'ari., A. Mahmudi., and E. Nuerlaelah, Our Prospective Mathematic Teachers Are Not Critical Thinkers Yet, Journal on Mathematics Education, 8(2), 145-156, 2017.

[2] S. Sujatmika., M. Irfan., T. Ernawati,., A. Wijayanti., and S.A. Widodo, Designing E-Worksheet Based On Problem-Based Learning To Improve Critical Thinking. ICSTI 2018, October 19-20, Yogyakarta, Indonesia, 1-8. https://doi.org/10.4108/eai.19-10-2018.2281282, 2019.

[3] C. Bardini., R. Pierce., J. Vincent., adn D. King, Undergraduate Mathematics Students' Understanding of the Concept of Function, Indonesian Mathematicall Society Journal on Mathematics Education, 5(2), 85-107, https://doi.org/10.22342/jme.5.2.1495.85-107, 2014.

[4] National Minister Education Regulation Number 22 Year 2006. Jakarta: Ministry of Education.

[5] A. N. Aini., M. Mukhlis., A. M. Annizar., M.H. Jakaria., and D. Septiadi, Creative thinking level of visual-spatial students on geometry HOTS problems Creative thinking level of visual-spatial students on geometry HOTS problems, Journal of Physics: Conference Series, 1465(2020), 1-7, https://doi.org/10.1088/1742-6596/1465/1/012054, 2020.

[6] D. Tall, Advanced mathematical thinking (Vol. 11), Springer Science \& Business Media, 1991.

[7] M. R. Muqtada., S. Irawati., and A. Qohar, Reciprocal Teaching assisted by GeoGebra to Improve Students Mathematical Communication, Jurnal Pendidikan Sains, 6(4), 238-246, 2018.

[8] K. Yuliani., and S. Suragih, The Development Of Learning Devices Based Guided Discovery Model To Improve Understanding Concept And Critical Thinking Mathematically Ability Of Students At Islamic Junior High School Of Medan, Journal of Education and Practice, 2015.

[9] K. A. Bakar., A. F. M. Ayub., R. A. Tarmizi., and W. S. Luan, Effect of teaching mathematics using GeoGebra on students' with dissimilar spatial visualisation, AIP Conference Proceedings, https://doi.org/10.1063/1.4932469, 2015.

[10] B. Kusumaningrum., M. Irfan., D. Agustito., Z. Wijayanto., and Z. Ratih, Spatial ability of student in construct volume of the solid of revolution graphic, Journal of Physics: Conference Series, 1315(1), 012032, https://doi.org/10.108 8/1742-6596/1315/1/012032, 2019.

[11] Z. Güney, Visual Literacy and Visualization in Instructional Design and Technology for Learning Environments, 
European Journal of Contemporary Education, 8(1), 103117. https://doi.org/10.13187/ejced.2019.1.103, 2019.

[12] J. A. Walle, K. S. Van de, Karp., and J. M. Bay-Williams, Elementary and Middle School Mathematics: Teaching Developmentally. http://books.google.com/books?id=aIYQ PQAACAAJ, 2010.

[13] M. Giaquinto., and M. Giaquinta, Visual thinking in mathematics, Oxford University Press, 2007.

[14] R. H. McKim, Experiences in visual thinking, 1972.

[15] D. Tall, The transition from embodied thought experiment and symbolic manipulation to formal proof. Proceedings of Kingfisher Delta, 5, 23-35, 2005.

[16] W. Hwang., J. Su., Y. Huang., and J. Dong, Study of Multi-Representation of Geometry Problem Solving with Virtual Manipulatives and Whiteboard System, Journal of Educational Technology \& Society, 12(3), 229-247, 2009.

[17] S. Winarno., K. S. Muthu., and L. S. Ling, Direct Problem-Based Learning (DPBL): A Framework for Integrating Direct Instruction and Problem-Based Learning Approach, International Education Studies, 11(1), 119. https://doi.org/10.5539/ies.v11n1p119, 2017.

[18] B. Lucas, A five-dimensional model of creativity and its assessment in schools., Applied Measurement in Education, 29(4), 278-290, 2016.

[19] M. A. Nuha., S. B. Waluya., and I. Junaedi, Mathematical creative process wallas model in students problem posing with lesson study approach. International Journal of Instruction, https://doi.org/10.12973/iji.2018.11236a, 2018.

[20] M. Wojciehowski., and J. Ernst, Creative by Nature: Investigating the Impact of Nature Preschools on Young Children's Creative Thinking. International Journal of Early Childhood Environmental Education, 6(1), 3-20, 2018,

[21] Y. S. Lin, Fostering Creativity through Education - A Conceptual Framework of Creative Pedagogy. Creative Education, 02(03), 149-155. https://doi.org/10.4236/ce.201 1.23021, 2011.

[22] R. Nemirovsky., and T. Noble, On mathematical visualization and the place where we live. Educational Studies in Mathematics, 33(2), 99-131, https://doi.org/10.1 023/a:1002983213048, 1997.

[23] F. Salvetti., and B. Bertagni, An e-REAL Lab in Dubai. Immersive Experiences, Visual Communication and Augmented Reality. International Journal of Advanced Corporate Learning (IJAC). https://doi.org/10.3991/ijac.v8i 3.4912, 2015.

[24] S. Stokes, Visual literacy in teaching and learning: A literature perspective. Electronic Journal for the Integration of Technology in Education, 1(1), 10-19, 2002.

[25] S. Bolton, The Visual Thinking Method. The Routledge Companion to Design Research, 277-291, 2015.

[26] M. Artigue., N. Iranzo., J. M. Fortuny., A. Leung., Y. Chan., F. Lopez-Real., and P. Rabardel, Model-Centered Learning: Pathways to Mathematical Understanding Using GeoGebra, Cuadernos de Investigación En Educación Matemática, 8, 91-103, 2011.

[27] J. Preiner, Introducing dynamic mathematics software to mathematics teachers: the case of GeoGebra (Doctoral dissertation in Mathematics Education, University of Salzburg, Salzburg, Austria). Recuperado de Http://Www. Pucrs.Br/Ciencias/Viali/Tic_Literatura/Teses/Preiner_Judit h.pdf, 2008.

[28] F. Fitriani., T. S. Maifa., and H. Bete, Pemanfaatan Software Geogebra dalam Pembelajaran Matematika. Jurnal Pendidikan dan Pengabdian Masyarakat, 2(4), 2019.

[29] Y. W. Li, Transforming Conventional Teaching Classroom to Learner-Centred Teaching Classroom Using Multimedia-Mediated Learning Module. International Journal of Information and Education Technology, 6(2), 105-112, https://doi.org/10.7763/IJIET.2016.V6.667, 2016.

[30] W. L. Yap., M. Neo., and T. K. Neo, Transforming from conventional teaching environment to learner-centred teaching environment with the use of interactive multimedia module in tertiary education. Proceedings of the International Conference on E-Learning, ICEL, 2016.

[31] R. Hake. Interactive-Engagement Versus Traditional Methods: A Six-Thousand-Student Survey of Mechanics Test Data for Intoductory Physics Courses. American Journal of Physics, 66(1), 1998.

[32] K. M. Kim., and R. Md-Ali, Geogebra: Towards realizing 21st century learning in mathematics education. Malaysian Journal of Learning and Instruction, 2017.

[33] H. Zulnaidi., and E. Zakaria, The effect of using GeoGebra on conceptual and procedural knowledge of high school mathematics students. Asian Social Science, https://doi.org/ 10.5539/ass.v8n11p102, 2012.

[34] H. Zulnaidi., and E. Zakaria, The effect of using GeoGebra on conceptual and procedural knowledge of high school mathematics students. Asian Social Science. https://doi.org/ 10.5539/ass.v8n11p102, 2012

[35] M. F. Ocal, The Effect of Geogebra on Students' Conceptual and Procedural Knowledge: The Case of Applications of Derivative. Higher Education Studies, https://doi.org/10.55 39/hes.v7n2p67, 2017. 